\title{
Age of the Mo-Clay Formation
}

\author{
JENS MORTEN HANSEN
}

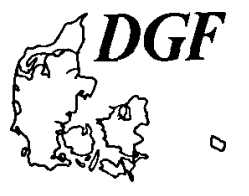

\author{
Hansen, J. M.: Age of the Mo-Clay Formation Bull. geol. Soc. Denmark, vol. 27, pp. 89-91. \\ Copenhagen. March 23rd, 1979. https://doi.org/10.37570/bgsd-1978-27-08 \\ On the basis of dinoflagellates the Mo-Clay Formation of Denmark can be assigned to the Upper \\ Paleocene and Lower Eocene.
}

Jens Morten Hansen, Geological Survey of Denmark, Thoravej 31, DK-2400 København NV, Denmark, February 10th, 1978.

On the basis of silicoflagellates the Mo-Clay Formation, including a series of ash layers numbered from -39 to +140 (Bøggild 1918), has recently been stated to comprise a time span from the Lower Paleocene to the Lower Eocene (Martini 1977) corresponding to nannoplankton zones NP 4 - NP 10 (Martini 1971). The lithostratigraphical position of the Mo-Clay is well-known (Dinesen, Michelsen \& Lieberkind 1977), overlying the Type Selandian (Rosenkrantz 1924). Haq \& Lohmann (1976) assigned the Lellinge Greensand (Lower Selandian) to NP 5, and the Type Danian sediments to NP 1 - NP 4. K. Perch-Nielsen (pers. comm. 1978) is in agreement with this. On the other hand, however, Martini (1977: 104) assigned the lowest part of the Mo-Clay as well as the Kerteminde Clay (= Kerteminde Marl) to NP 4, which is of Upper Danian age. The Kerteminde Marl directly overlies equivalents to the Lellinge Greensand (or Copenhagen Greensand), and there is thus some discrepancy between the nannoplankton and silicoflagellate zonation of the Palaeogene of Denmark (cf. also Perch-Nielsen 1976).

However, samples from the Mo-Clay (-33/-34) and of the underlying grey, slightly calcareous clay in Stolle Klint on Fur yielded abundant and well preserved dinoflagellates unquestionably belonging to the Wetzeliella hyperacantha Zone of Costa \& Downie (1976), which is almost equivalent to NP 9 (Costa \& Downie 1976). Typical $W$. hyperacantha Zone assemblages continue until ashlayer $-19 \mathrm{~b}$, where the dinoflagellate assemblage becomes completely dominated by Cyclonephelium ordinatum. The first occur- rence of Wetzeliella spp. is a world wide biostratigraphic marker (Wilson 1967, Downie, Husain \& Williams 1971, Costa \& Downie 1976) defining the base of the $W$.'hyperacantha Zone. The presence of Wetzeliella in the Mo-Clay has previously been mentioned by Perch-Nielsen (1976:28). Furthermore, a sample of greyish clay below typical Røsnæs Clay, which latter belongs to NP 11 (Perch-Nielsen 1976:28), and above ash layer +130 in Knude Klint on Fur contained $W$. meckelfeldensis showing that the Mo-Clay perhaps extends into the $W$. meckelfeldensis Zone of Costa \& Downie (1976). This is supported by an investigation by Caro (1973:340) who found $W$. articulata in the Røsnæs Clay, which therefore may be correlated with the $W$. varielongituda Zone or younger strata. The $W$. varielongituda Zone makes up a minor part of NP 11 , whereas the $W$. meckelfeldensis Zone is correlated with parts of the Lower Eocene NP 10 (Costa \& Downie 1976) corresponding to the basal Ypresian (de Coninck 1965, 1968 \& 1972). Haq \& Lohmann (1976:128) correlated the Røsnæs Clay with NP 11 - NP 13.

Since the Mo-Clay in Hanklit and Silstrup Klint extends above +130 we may conclude that the Mo-Clay extends into the Lower Eocene $W$. meckelfeldensis Zone (NP 10), and since the Mo-Clay in Stolle Klint as well as the underlying grey slightly calcareous clay belongs to the $W$. hyperacantha Zone (NP 9), we can further conclude that the lower part of the Mo-Clay is of Upper Paleocene age, and that the Mo-Clay certainly does not include sediments belonging to NP 4, (compare Fig. 1). 


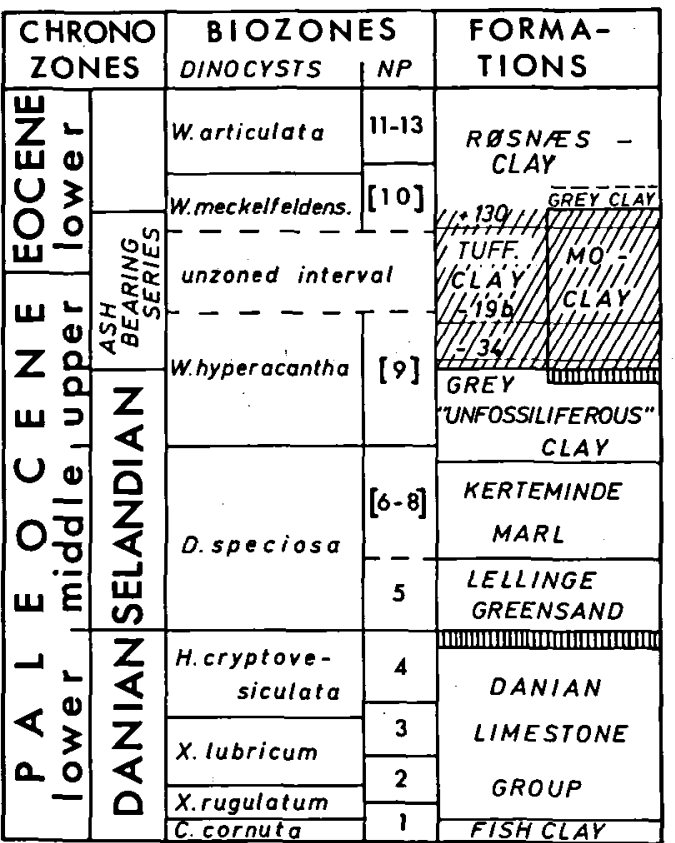

Fig. 1. Biostratigraphic correlation of the Paleocene - Lower Eocene of Denmark. Brackets indicate correlations based on indirect evidence. W. $=$ Wetzeliella, D. = Deflandrea, $\mathrm{H}$. = Hafniasphaera, $\mathbf{X} .=$ Xenicodinium, $\mathbf{C} .=$ Carpatella. Tuff. clay: tuffbearing clay.

Dinoflagellates from the grey, slightly calcareous (socalled unfossiliferous) clay below the Mo-Clay, Stolle Klint, Fur:

Wetzeliella hyperacantha, W. homomorpha homomorpha, W. homomorpha quinquelata, Cyclonephelium ordinatum, Operculodinium centracarpum, Membranilarnacia ursulae, Deflandrea speciosa, D. wardenensis, D. phosphoritica australis, D. depressa, Alterbia dilwynensis, Diphyes colligerum, Phthanoperidinium tritonium.

Dinoflagellates from the Mo-Clay $(-33 /-34)$, Stolle Klint, Fur:

Wetzeliella hyperacantha, W. homomorpha homomorpha, W. homomorpha quinquelata, Cyclonephelium ordinatum, Deflandrea speciosa, $D$. phosphoritica australis, Spiniferites ramosus, $O p$ erculodinium centrocarpum, Hafniasphaera septata, Hafniasphaera sp.

Dinoflagellates from the Mo-Clay $(-20 /-19 b)$, Stolle Klint, Fur:
Wetzeliella hyperacantha, W. homomorpha homomorpha, $W$. homomorpha quinquelata, $W$. paniculata, Cyclonephelium ordinatum, Hystrichosphaeridium tubiferum, Hafniasphaera sp., Operculodinium centrocarpum, Cordosphaeridium inodes.

Dinoflagellates from greyish clay above +130 , below Røsnas Clay, Knude Klint, Fur:

Wetzeliella meckelfeldensis, Cyclonephelium ordinatum, Hystrichosphaeridium tubiferum, Spiniferites ramosus, $S$. cornutus, Oligosphaeridium complex, Cordosphaeridium inodes gracilis, Hafniasphaera septata, Hafnisaphaera sp., Operculodinium centrocarpum, Deflandrea phosphoritica phosphoritica, D. depressa.

Acknowledgements. C. Heilmann-Clausen is thanked for giving me samples. N. Bonde is thanked for many discussions of the stratigraphy. R. G. Bromley kindly improved the English of the manuscript. The present study was supported by grants from the Danish Natural Science Research Foundation.

\section{Dansk sammendrag}

På grundlag af fossile dinoflagellater kan moleret korreleres med Wetzeliella hyperacanta Zonen, som desuden omfatter det såkaldte grå, fossilfri ler under moleret. Moleret synes desuden at nå ind $\mathrm{i}$ den næstfølgende dinoflagellatzone, $\boldsymbol{W}$. meckelfeldensis Zonen. På basis af disse zoners korrelation med Type Ypresien og med Paleocæn-Eocæn sedimenter andre steder $i$ verden kan det konkluderes, at moleret er aflejret i Øvre Paleocæn (NP 9) og sandsynligvis også i Nedre Eocæn (NP 10), hvilket synes at modbevise Martinis (1977) korrelation af moleret med væsentligt ældre aflejringer.

\section{References}

Bøggild, O. B. 1918: Den vulkanske aske i Moleret. Danmarks geol. Unders. (2), 33: $159 \mathrm{pp}$.

Caro, $\bar{Y}$. 1973: Contribution a la connaissance des dinoflagellés du Paléocène-Eocène inférieur des Pyrénées espagnoles. Rev. Españ. Micropal. 5 (3): 329-372.

Costa, L. \& Downie, C. 1976: The distribution of the dinoflagellate Wetzeliella in the Palaeogene of northwestern Europe. Palaeontology 19: 591-614.

Coninck, J. de, 1965: Microfossiles planctoniques du sable Yprésien à Merelbeke. Dinophyceae et Acritarcha. Mém. Acad. roy. Belge, cl.sci., sér. 8, 41:1-54.

Coninck, J. de, 1968: Dinophyceae et Acritarcha de l'Yprésien du sondage de Kallo. Inst. roy. Sci. nat. Belgique, mém. 161:1-64

Coninck, J. de, 1972: Application stratigraphique des microfossiles organiques dans l'Yprésien du Bassin Belge. Bull. Soc. belge Geol. Paléont. Hydrol. 81:1-11.

Dinesen, A. Michelsen, O. \& Licberkind, K. 1977: A survey of the Paleocene and Eocene deposits of Jylland and Fyn. Danmarks geol. Unders. ser. B, 1, 15 pp. 
Downie, C., Husain, M. A. \& Williams, G. L. 1971: Dinoflagellate cysts and acritarch associations in the Palaeogene of south-east England. Geoscience and Man, 3: 29-35.

Haq, B. U. \& Lohmann, G. P. 1976: Early Cenozoic nannoplankton biogeography of the Atlantic Ocean. Marine Micropaleontology, 1: 119-194.

Martini, E. 1971: Standard Tertiary and Quaternary calcareous nannoplankton zonation. In: Farinacci: Proc. 2nd planktonic Conf. Roma 1970: 739-785.

Martini, E. 1977: Neue Daten zum Paläozän und Unter-Eozăn im südlichen Nordseebecken. Newsl. Stratigr. 6: 97-105.

Perch-Nielsen, K. 1976: New silicoflagellates and silicoflagellate zonation in north European Palaeocene and Eocene diatomites. Bull. geol. Soc. Denmark, 25: 27-40.

Rosenkrantz, A. 1924: De københavnske Grønsandslag og deres Placering i den danske Lagrakke. Meddr dansk geol. Foren. 9: 1-39.

Wilson, G. 1967: Some species of Wetzeliella Eisenack (Dinophyceae) from New Zealand Eocene and Paleocene strata. N. Z. J. Bot., 5: 469-497. 